International Journal of Instruction e-ISSN: 1308-1470 • www.e-iji.net

Article submission code: 20210207085233

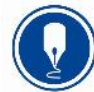

January $2022 \bullet$ Vol.15, No.1

p-ISSN: 1694-609X

pp. 965-984

Received: 07/02/2021

Revision: 24/08/2021
Accepted: 20/09/2021

OnlineFirst: 10/12/2021

\title{
English Teachers' Competency in Flipped Learning: Question Level and Questioning Strategy in Reading Comprehension
}

\section{Reflianto}

Dr. candidate, Universitas Negeri Malang, Indonesia, refliantomuslim@gmail.com

\section{Punaji Setyosari}

Universitas Negeri Malang, Indonesia, punaji.setyosari.fip@um.ac.id

\section{Dedi Kuswandi}

Universitas Negeri Malang, Indonesia, dedi.kuswandi.fip@um.ac.id

\section{Utami Widiati}

Universitas Negeri Malang, Indonesia, utami.widiati.fs@um.ac.id

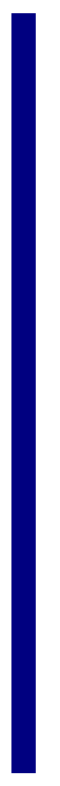

\begin{abstract}
Questioning skills are significant competencies that English teachers must possess in teaching reading narrative texts. These competencies include the ability to create various levels of questions and strategies. This study aimed to investigate the teachers' competence in making question levels, strategies, and teachers' and students' responses during the online flipped classroom learning process. This study used a qualitative approach with a content analysis design. The data analysis used Barrett's taxonomic percentage, Jacobsen's questioning strategy theory, and content analysis through condensation, identification, labeling, grouping, verification, and concluding. This study revealed that the competence of teachers in making question levels and questioning strategies had unique skills. Remarkably, the teachers' training background did not wholly affect their competence. However, language insight, technology mastery, and question habit dominantly influenced their ability to combine the question levels according to the questioning strategy. The responses of students taking part in the learning provided positive feedback for improving reading comprehension skills. The teachers' response stated that this method encourages active student engagement in each online teaching session and eases their reading comprehension skills. We suggested English teachers improve their linguistic understanding, teaching technical skills, and strengthen two-way interaction with students through questionand-answer sessions.
\end{abstract}

Keywords: English teacher' competency, question level, questioning strategy, flipped learning, reading 


\section{INTRODUCTION}

In language learning, reading comprehension is one of the language skills. Reading has received more attention than any other aspect of education. The ability of it is the basis for successful learning and cognitive skills. Reading is also a basic foundation in the learning process well (Lervåg et al., 2009). Reading comprehension depends on language comprehension and word reading skills (Perfetti, 1976; Gough \& Tunmer, 1986). Thus, in the learning process, teachers need to ask various questions to guide understanding. This behavior is a manifestation of the teachers' competence in teaching languages. This competence to explore students' reading skills can lead by using questioning strategies.

The questioning strategy used aims to activate and motivate students to take part in the teaching and learning process. David et al. (1989) stated that there are three questioning strategies used in reading classes, namely: redirection, prompting, and probing. Redirection and prompting questions help establish positive patterns and active student interactions in the classroom. Using these strategies can lead students to find some clues in answering the questions well. They also can understand the meaning, catch the message and be able to conclude it. Cooper (2010) revealed that the probing question in the class as teaching skills is useable to improve students' high-level thinking skills in understanding a reading text in the EFL reading class. This ability is well-known in Bloom's Taxonomy theory (Bloom et al., 1956). Bloom classifies this thinking ability into six hierarchies: knowledge, understanding, application, analysis, synthesis, and evaluation.

Besides Bloom's taxonomy, Beret also introduces the related theory called Barrett's taxonomy. This theory describes the specific results of a reading comprehension process He invented this as a guide for teachers in using different questions in reading instructions. He proposes five major categories: (a) literal understanding, (b) reorganization understanding, (c) inferential understanding, (d) evaluation understanding, and (e) appreciative understanding (Smith \& Barrett, 1979).

In the teaching process, the questions asked are directing students to understand and underline the text messages they read. Teachers are professional question makers, and their ability to create questions is one way for them to stimulate students' thinking to understand a reading text (Curtis, 2012). We relate it consistent with the research of Dos et al. (2016) revealed that training and the pre-service education teacher affect their competence in teaching in the class. Besides, on-the-job training can also improve teacher competence in teaching.

Teacher competence in teaching students can encourage student engagement as expected to become independent learners, who actively use technology for learning outside the classroom. Teachers, as significant social agents who shape students' intellectual and social experiences, have an important role to play in promoting autonomous language learning with technology outside the classroom (Lai et al., 2016). The active engagement of students in the question-and-answer session with their teachers went well because students had gained an initial knowledge of the material discussed during 
studying outside the classroom. Usually, teachers give reading comprehension assignments a week before the online class starts, which has been a habit for teachers since the COVID-19 pandemic outbreak, including in Indonesia.

The outbreak of the COVID-19 in the world has forced the government to close schools and universities in over 213 countries. This situation has introduced many people to switch from traditional learning to online learning. The nationwide COVID-19 lockdown has forced K-12 universities and schools to close and send their students home, at least over $91 \%$ of the world's student population forced to study from home. Many countries continue to manage this disorder by implementing various learning methods through a combination of technologies. Almost all countries encouraged teachers and school administrators to stay in touch with students through virtual-based learning or online learning (Harrison, 2021). In Indonesia, this condition has reformed the traditional teaching model into a technology-based teaching model. It is an extreme change that brings various challenges to a teacher in its implementation in the field.

One challenge faced by English teachers in Indonesia is their readiness to provide online learning processes, including the continuity of learning English in schools. In online learning, teachers are ready to improve their competency, especially using various virtual learning tools such as WhatsApp, Facebook, Instagram, Zoom Meeting, Google Classroom, and Microsoft Team. However, the effectiveness of online learning related to teaching competence based on question level and questioning strategies is a few so far. For this reason, it is necessary to conduct studies that are useful for teachers in designing teaching methods that are following the learning needs of students during the current COVID-19 pandemic.

The online-based flipped classroom teaching method is a teaching that has two parts, namely learning activities outside the classroom and online class session learning activities. In the flipped classroom online learning method, the teachers first give assignments to all students to learn independently and increase their learning potential at home. Before starting online classes, all students must actively study in offline groups. They also have to be active in group learning to do all the assigned tasks (Henderson et al., 2020; Martin \& Tapp, 2019).

There are many studies related to the flipped classroom method of learning to read comprehension. Previous research Chavangklang \& Suppasetseree (2018) revealed that the flipped cooperative-classroom model (FCCM) could improve Thai EFL reading comprehension. It also makes a positive impact on implementing the FCCM strategy. Furthermore, Sencibaugh \& Sencibaugh (2015) reported that the questioning strategy had a statistical effect on the reading comprehension achievement of all observed students. Chen Hsieh et al. (2017) revealed that students' motivation and actions using idioms improved following written and oral online flipped learning. This way also significantly improved their idiomatic knowledge, showing that the flipped learning was successful in achieving the instructional goals of the classroom.

Another research on guided questioning strategies using flipped classrooms toward students' reading comprehension skills by Brown et al. (2016) revealed that the guided 
reading questions positively impact student motivation, reading comprehension, effort level, and understanding of the material before attending class. Other research related to the strategy of asking questions by Joseph et al. (2016) reported that to improve students' self-confidence and enhance reading comprehension performance across a range of diverse learners and various educational settings needs teachers' competence in using a questioning strategy in EFL Class.

Referring questioning strategy research executed by Liu (2020) revealed significant interactions between questioning strategies and comprehension measures, controlling for individual-level differences in first language reading ability (L1), L2 vocabulary size, and topic familiarity. Using a questioning strategy significantly facilitates student comprehension in answering the questions that require brief answers but not multiplechoice questions. There are three themes regarding L2 readers' perceptions of questioning strategies: identifying and memorizing text details, understanding main ideas, and interfering with reading fluency.

The researches mentioned above showed that all previous studies focused more on measuring the ability to understand text using the flipped classroom method, questioning strategies, learning technology, and reader perception. Meanwhile, the success of teaching reading comprehension also depends on the competence of teachers and their cognitive ability to make various levels of questions and questioning strategies that can lead students to give correct answers during question and answer. So far, a few people relate current research of teachers' competency with their ability to create questions levels and questioning strategies in class, even though both competencies are a significant influence on student achievement. The more competent the teachers' questions to students, the easier it is for students to find the correct answer about the material asked. Joseph and Liu's previous research still has not revealed the role of teacher competence in creating questions level and using questioning strategies in class on their teaching performance in a qualitative study. They reported that teacher competence in teaching also affects students' reading comprehension skills statistically. In qualitative, previous research limitation has not discussed yet, only focus on measuring the effectiveness of the flipped classroom method on students' reading comprehension skills. Many studies do not reveal how teachers' competence in creating question and strategy affect students' reading comprehension qualitatively in a teaching process. They also have not analyzed the extent to which the use of methods, teacher educational background, experience, and training contribute to teacher competence in making question levels and questioning strategies. A few current related studies are still insufficient and make our needs to investigate more deeply.

It is a novelty of this research, which is measuring the teachers' competence to use question levels and questioning strategies using online flipped classroom learning in qualitative. It also assists English teachers in designing online learning for reading comprehension subjects during the COVID-19. In-depth, this research also analyzed the responses of teachers and students regarding the use of the online flipped classroom method in supporting teacher competence to improve students' reading comprehension skills. 


\section{Research question}

The research formulation describes the teacher's competence in using level questions and asking strategies in the online-based flipped classroom method. To answer this formulation, the following research questions were:

1. How is the teachers' competence in using question levels in learning to read comprehension in an online-based flipped classroom?

2. How is the competence of teachers using questioning strategies in learning to read comprehension in an online-based flipped classroom?

3. How do teachers and students respond to the level of questions and strategies in learning to read comprehension in an online-based flipped classroom?

\section{METHOD}

\section{Design, Participants and Procedure}

This study used a qualitative approach with a content analysis design. It aimed to measure the teachers' responses when using question levels and questioning strategies. The participants in this study were three English teachers who teach third-grade students of Vocational School majoring in management in Pariaman City.

We carried learning out in groups six times for six weeks for each class. Students must understand the text and answer reading questions as an initial task before the online face-to-face learning begins. We require students in each group to study independently for at least two hours a day and discuss the work done in their respective groups for ten hours per week. The teachers sent all reading materials and reading questions assignments via WhatsApp and Microsoft Team. Each student reported their work progress each week to the teachers via E-mail the day before the online class session started. In online class sessions, each group member presented their understanding of narrative texts discussed outside the previous class. After the presentation, the teacher asked leading and in-depth questions to evaluate comprehension of the text discussed through five levels of questions, are literal, reorganized, inferential, evaluation, and appreciation, and three questionings strategies are redirection, prompting, and probing. The process of teachers' and students' questions and answers during online learning sessions and out-of-class interviews with teachers and students is qualitative research data. We collected all this data using a smartphone recording instrument.

\section{Research Instruments and Data Collection}

The research instrument used interview forms and recordings, and validity and reliability of interviews questions refer to indicators of teacher competence in using question levels, questioning strategies, and student and teacher impressions of flipped online learning. Expert judgment validated the interviews form and tested its reliability. The teaching materials used narrative texts such as An Innocent Question, Richie's Phone Off, Old Woman and Her Cow, The Faithfull, Horse and The Fox, Ali Baba and the Forty Thieves, The Smartest Animal, and Loro Jongrang.

Data collection used a smartphone recording device to record the entire question-andanswer process between teachers and students in online class sessions and interviews with teachers and students outside the classroom. The coding of all teachers' utterances 
grouped into each type of question observed based on Barrett's Taxonomy and Jacobsen's and Eggen's theory. In collecting data, the researcher recorded all questions and answers between teachers and students in three different classes, namely Class-1 Management, Class-2 Management, and Class-3 Management. After getting data, the researcher wrote the all utterances transcript and then classified all the teachers' questions based on literal, reorganized, inferential, evaluation, appreciation, and three question strategies of redirection, prompting, and probing. Teacher and student responses to online-based flipped learning to use a recorded open interview form. This research took four months, starting from April 2020 to August 2020.

\section{Data analysis}

Research data analysis used descriptive statistics with percentage calculations. We did transcripts of all teachers' and students' utterances and diminished their unnecessary local language. We identified and grouped it based on question-level and questioning strategies. In the process of identification, labeling, and classifying, three observed Teachers: Teacher-1 were coded (T1), Teacher-2 (T2), and Teacher-3 (T3). Meanwhile, the observed students: Student-1 were coded (S1), Student-2 (S2), Student-3 (S3), Student-4 (S4), Student-5 (S5), so on. After collecting all conversational data, we explained the findings in tabular form and then concluded the research findings.

\section{FINDINGS}

\section{Question Level}

The qualitative data in this research were teacher utterances as questions posed to students and recorded during online learning sessions. The three teachers studied in this study were Teacher-1, age of 48 years old, had over twenty times of training experience, and had an active teaching period of 25 years. Teacher- 2 is 45 years old with over fifteen times training experience and has taught for 23 years, and Teacher- 3 is 35 years old with less than five times training experience, with only five years of teaching experience. The data in this study only took oral questions and answers data in online learning sessions using WhatsApp and Microsoft Team Teleconference.

The questions posed by the teachers at the literal level did not require high reasoning to answer. To answer this question, students only need to remember and memorize the storyline of the narrative text they read. One can respond quickly to the simple literal question what the teacher asked from the related paragraph.

\section{Question of Literal Level}

T1 : Very Good! Do you know how old was Bryan age? (Q9-:T1)

Look at the second paragraph in the first! (Calling name of student) (Q1:T1)

T1 : Could you describe! What does the characters of Bryan? (Q24:T1)

The questions above require students to recall the material learned example in the Q9$\mathrm{T} 1$ extract. It is to identify the age of the main character mentioned in the text, while in Q14-T1, students look for discussion topics directly. In the question of Q24-T1, teachers 
asked a student to describe more what Bryan's character is. The answer to this question can guess easily in the paragraph.

The next stage is the reorganization question level, where it is also still at a low level. Students could answer it immediately after reading the narrative text. This question asks students to understand the structure and plot of the story in the text. The students' ability to respond to these questions only needs their memory strength and the ability to understand the textual and contextual meaning. Students can understand the literal text and rearrange it well after they read the given narrative text. The student's task is to understand the content of the text presented by the author.

\section{Question of Reorganization Level}

T2 : That's correct, "What is the main idea of the first paragraph" (Q29-T2)

$\mathrm{T} 2$ : Jadi main paragraph one is...? (Q30-T2)

In the question of $\mathrm{T} 2(\mathrm{Q} 29-\mathrm{T} 2$ and 20-T2) also have similar instructions. The teacher poses these questions to students by asking related statements that focus on the subject, such as in the question of Q29-T2. She took this question after monitoring students' understanding of the topics covered. By asking this question, she thought the students had already understood some passages.

The inferential question level is at the high order thinking question. Students could not answer this question type immediately after reading the narrative text if they did not do deep analysis. This question asks students to understand the structure of the storyline and to conclude it. The students' ability to respond to inferential questions needs their high order thinking to understand the textual and contextual meaning. The following transcription from T2's question:

\section{Question of Inferential Level}

T2 : What is it? maksudnya apa? Apa artinya? (Q35-T2)

T2 : Good, what does Bandung Bandawasa Personally like (Q18-T2)?

T2. : Yang menarik dari Bandung Bandawasa, selain menang perang dan punya tenaga supernatural, apalagi? (Is there anything interesting from Bandung Bandawasa besides winning the war and have supernatural power what's else?) (Q37-T2)

In the question of Q35-T2 and Q18-T2, the teacher asked the students to estimate whether the students understanding the content of the text. While in the question of Q37$\mathrm{T} 2$, the teacher had to provide some information about the Kingdom of Prambanan and Bandung Bandawasa. They also asked the student to summarize the story after reading the text. Therefore, students should recall their prior knowledge to answer the question of Q37-T2 because the text condition can not always be a reference to get answers to questions explicitly from the paragraph asked. The T2 method asked students to translate all the questions first, after understanding, then answer them. Thus, the goal is achievable by helping students produce good feedback. However, Dean et al. (1986) and 
Kim \& Petscher (2020) stated that this method is allowable to find out which students have previous learning experiences outside the class regarding the text discussed in the online class session of question and answer.

\section{Question of Evaluation Level}

T3 : What moral value can you get from the story? (Q155-T3)

S1 : [no response]

T3 : Bagaimana Riska? (Q156-T3)

S2 : The strength is not everything.

T3 : Okay...

S3 : I think. emmm...every people must be faithful to each other.

T3 : Very good, thank you.

T3 asked students to evaluate what moral values from the story got. During question and answer in the class, the teacher gives instructions about searching for the moral message in a narrative text. It aimed to make it easier for them to know where moral values are in a paragraph. Teacher asked students' responses to confirm that the answer can find out in the text. Based on the facts in the field, the asked question of "What moral value can you derive from the text?" When asked these questions to the first student, he did not answer, and then the teachers switch to another student. He replied that "Strength isn't everything." The teacher appreciated his answer, "you are wonderful," and she said, "What is else, Fina?" She answered, "I think everyone must be loyal to each other." The teacher replied. "Well done."

It is the way of making judgments about whether students understand the text. It is consistent with previous research by Dhillon et al. (2020) that such questions in the skimming method can help students see the underlying ideas in a paragraph/story. The teacher should reward them for matching significant facts so that students can answer questions based on their experience and knowledge. The question of appreciation level showed that only $\mathrm{T} 3$ teachers could make questions at this level, which is $6 \%$. Meanwhile, T2 and T1 did not create it. Here are some excerpts from the T3 teacher appreciation level questions.

\section{Question of Appreciation Level}

T3 : Dave pretends to be busy calling a client that turns out to be a connection they have not installed the phone, it's funny

S1 : cute, Ma'am!

T3 : If the conditions like that, what words will describe the feeling of Dave? (Q131-T3)

S2 : shame, Ma'am! 
T3 : yes ... what would you do if you were Dave?" (Q132-T3)

S3 : ashamed, I don't know what to say.

The study results revealed that the observed three teachers, only one of them, made questions of appreciation level with the inquiry. There are differences between teachers in applying these levels of questions. This difference does not depend on the amount of experience taking part in learning, active teaching period, and age, but on literacy and language mastery skills, mastery of learning technology, and teacher habits in applying question-and-answer-based online teaching.

During learning, the teacher gives instructions to direct students to get the correct answer. Therefore, it is not uncommon for T1, T2, and T3 to do code-switching using Indonesian in the learning process when students have difficulty understanding the questions asked. The observations of the three teachers in teaching reading comprehension using the online-based flipped classroom method showed that her ability to make questions and strategies was quite good. The following is a recapitulation of her utterance in various questions posed to students during online class sessions.

Table 1

Teacher's question levels in teaching reading comprehension using the online flipped classroom method

\begin{tabular}{llllllllll}
\hline \multirow{2}{*}{ Question level } & \multicolumn{2}{c}{ Teacher-1 } & \multicolumn{2}{c}{ Teacher-2 } & \multicolumn{2}{c}{ Teacher-3 } & \multicolumn{2}{c}{ Total } \\
\cline { 2 - 10 } & $\mathrm{Q}$ & $\%$ & $\mathrm{Q}$ & $\%$ & $\mathrm{Q}$ & $\%$ & $\mathrm{Q}$ & $\%$ \\
\hline Literal & 90 & 49.2 & 62 & 39.7 & 85 & 36.5 & 237 & 41.4 \\
\hline Reorganization & 52 & 28.4 & 67 & 42.9 & 60 & 25.8 & 179 & 31.3 \\
\hline Inferential & 23 & 12.6 & 6 & 3.8 & 33 & 14.2 & 62 & 10.8 \\
\hline Evaluation & 18 & 9.8. & 21 & 13.5 & 40 & 17.2 & 79 & 13.8 \\
\hline Appreciation & 0 & 0 & 0 & 0 & 15 & 6.4 & 15 & 2.6 \\
\hline Total & 183 & 100 & 156 & 100 & 233 & 100 & 572 & 100 \\
\hline
\end{tabular}

The three teachers studied had the same ability almost in making the level of literal questions. T1 could create about 90 question items (49.2\%) of the total 183 questions made. T3 about 85 question items created (36.5\%) of 233 questions made. T2 asked the literal questions $62(39.7 \%)$ of the total 156 questions made. At the inferential questioning level, T1 could ask more questions than others by 23 questions (12.6\%) of 183 questions made. T2 is the lowest questioning ability at this level, which is only six questions $(3.8 \%)$ of the total 156 questions made. T3 is better than the first and second teachers in making inferential questions of 33 questions (14.2\%) of 233 questions made. Similarly, for appreciation level, T3 is slightly better than the first and second teachers. She created 15 questions (6.4\%) of 233 questions.

\section{Questioning Strategy}

The teacher used a questioning strategy with the online flipped classroom learning method to help improve student understanding well. The first teacher can direct students in questions and answers that lead to a redirection strategy. 


\section{Redirection Strategy}

T1 : Okay, my students! Did you still remember the last subject with me? (Q83-T1)

T1 : That's correct, betul ya kapan kejadiannya, semua itu terletak di paragraf pertama. Selanjutnya, the next question is what the second paragraph content? (Q99-T1)

From the transcription above, all teachers apply this strategy at the beginning of their teaching-learning process. It aims to help students form positive thinking patterns about narrative texts. Applying an online-based flipped classroom method using question level and questioning strategy is one of the English teachers' efforts to increase students' engagement. Teachers can use this method to maintain high student interest and enthusiasm for learning.

Simple questions allow students to answer them better. Three questioning strategies, namely redirection, prompting, and probing, can help teachers direct and guide students in answering questions correctly. This ability guide students to think highly to get the correct answers to the questions posed by the teacher (Joseph et al., 2016). These results explained questions Q134b and 135b about the chronological sequence of events in the narrative text of Ali Baba and the Forty Thieves to explore students' knowledge in depth. Teachers use question prompting and probing strategies to evaluate their students' understanding of the narrative text.

\section{Prompting Strategy}

T2 : Do you know what the Prambanan temple? Ada yang tahu apa itu Candi Prambanan? (Is there any know what the Prambanan temple?) (Q10-T2)

S2 : Candi Prambanan Ma'am!

T2 What else? (Q11-T2)

S3 : The temple which is in Central Java, Ma'am

$\mathrm{T} 2$ : trus ada lagi? apa? (Q12-T2)

S2 : Candi Loro Jongrang Ma'am!

$\mathrm{T} 2$ : Anything else? (Q13-T2)

S3 : candi yang dibangun oleh Bandung Bandawasa Ma'am. (Bandung Bandawasa $\mathrm{Ma}$ 'am built the temple)

$\mathrm{T} 2$ : apa nama lain dan apa yang menarik dari candi tersebut? (What the other name of Prambanan temple and what's the interesting about it?) (Q14-T3)

S3 : Loro Jongrang Temple Ma'am.

T2 : Good and what does it interesting about it? (15-T2)

S1 : bisa untuk rekreasi Ma'am

$\mathrm{T} 2$ : According to you who build the temple? Siapa yang membangun candi itu? (Q16-T2) 


\section{S6 : Bandung Bandawasa Ma'am!}

$\mathrm{T} 2$ : Ya, jadi ceritanya yang membangun candi itu adalah Bandung Bandawasa atas permintaan siapa? (17-T2)

S2 : Loro Jongrang Ma'am?

Transcription of T2 utterance asked the same questions as Q10-T2. When given prompting question cannot answer by students, teachers move to other students who can reply to the question by finding refers listed in the clue of a paragraph. T2 asked again by asking questions as in Q11-T2. However, the students did not respond. After the teacher waited for a while, another student answered this question. Then, she moved on to the next question in Q12-T2. The question is still the same as the previous question. She created this method to monitor students' understanding. After discussing the text, the teacher challenged them to name how many temples are in Central Java. Students could answer these questions by doing synthesize text. Therefore, the last question is also easy for students to answer. Students can get this information from the instructions provided.

\section{Probing Strategy}

T3 : Good boys, but work hard even though it is stealing, because if they caught you, you risk your life (Q134-T3)

T3 : Did Ali Baba succeed in tricking the thieves? (Q135-T3)

S3 : Yes, Ma'am, Ali Baba and his wife lived happily ever after.

The two questioning strategies above in teaching reading comprehension to students with the online flipped classroom method can lead students to higher thinking levels. They can analyze, evaluate an event in the narrative text so that they can conclude correctly. The strategy of teacher investigating questions always provides a developed response simultaneously. The next question is arising from previous feedback of students is a continuous series of questions. Probing can encourage student responses more focused on the related series of questions following the launched questions earlier. The following is a recapitulation of the teachers' words in asking questions that apply three questioning strategies.

Table 2

Teacher's questioning strategy in teaching reading comprehension using the online flipped classroom method

\begin{tabular}{lllllllll}
\hline \multirow{2}{*}{ Questioning Strategy } & \multicolumn{2}{l}{ Teacher-1 } & \multicolumn{2}{l}{ Teacher-2 } & \multicolumn{2}{c}{ Teacher-3 } & Total & \\
\cline { 2 - 11 } & $\mathrm{Q}$ & $\%$ & $\mathrm{Q}$ & $\%$ & $\mathrm{Q}$ & $\%$ & $\mathrm{Q}$ & $\%$ \\
\hline Redirection & 89 & 49 & 79 & 51 & 58 & 25 & 226 & 39.5 \\
\hline Prompting & 76 & 42 & 35 & 22 & 104 & 45 & 215 & 37.6 \\
\hline Probing & 18 & 10 & 42 & 27 & 71 & 30 & 131 & 22.9 \\
\hline Total & 183 & 100 & 156 & 100 & 233 & 100 & 572 & 100 \\
\hline
\end{tabular}

The three observed teachers had almost the same ability in directing the guiding questions. There are fewer differences in the competency in using redirection strategy in 
T3 from T1 and T2, but they have excellent skills. T1 mostly applied the redirection strategy in learning with 89 questions (49\%) of the 183 questions made and T2 with 79 $(51 \%)$ of the 156 questions. Teachers-3 who use the prompting questioning strategy is a few higher than T1 and T12, namely $104(45 \%)$ of the total 233 questions made. This value is higher than T1 with 76 items (42\%) and T2 with 35 question items (22\%). For the probing strategy, the most skilled in implementing it was T3. In contrast to T1 and T2, T3 allows making 71 questions or $30 \%$ of the total 233 questions made.

\section{Teacher and Student Responses}

During the learning process for reading comprehension online using the flipped classroom, there are at least three key points that can have entered as positive responses from teachers and students in online question-and-answer forums in virtual classes, including:

\section{Active Student Engagement and Teacher Competence}

The teacher carrying out reading comprehension learning with this online flipped classroom method can provide some sympathetic responses. The following is the response on flipped classroom method using a question-level and a questioning strategy: Using the online-based flipped classroom learning method is very interesting and can improve the ability to answer the questions I posed correctly to students. Even though I am not proficient in virtual learning, I am still trying to improve my competence. Indeed, sometimes it affects my competence in asking questions and implementing questioning strategies. I felt my performance decreased somewhat because of the burden of thinking that makes me more drained to maintain smooth use of WhatsApp and Microsoft Team features during a teleconference (T1).

The same expressed response by students who showed a strong interest in following this learning method: I am very interested in this learning method because it is fun and makes me learning independently to do my assignments at home. It also made my reading comprehension easier and better, especially when the teacher gave some assignments and reading comprehension tests. In addition, I was also more actively involved in the discussion session with the instructor eq: when the teacher asked, "What did little Bryan touch his mother?" I said it was "the nose." Then teacher guides the next question, "What is the conclusion of the text of An Innocent Question." I can answer questions well because the teacher directs me to find answers by providing paragraph clues that need attention (S1).

Other student responses also supported previous responses. During the flipped classroom online learning on reading comprehension material, I felt happy because the teacher allowed me to study and practice first at home to answer various reading comprehension assignments given. (S5).

The third teacher supports the previous statement stating: I feel the strength of this method lies in the mastery of the material well by the instructor and students before the online class session begins. So that when asking questions in online classes and supported by digital materials, it encourages the discussion process in virtual classes to 
be more fun and fluent. This condition made me more competent and trained to ask various questions and questioning strategies as well. Because I have already been using this online learning technology before, it makes me easier to adapt it during the COVID-19 pandemic. Some students have a slow response to the question asked using new vocabulary I could handle by using mixing code to make them easier to understand the meaning of the question I asked (T3).

\section{Self-Study Students}

Flipped classroom facilitates students to learn independently first in understanding the material given well before the online class session begins. The interview results with the second teacher stated: I have to continue to improve my ability in making five-level questions and get used to using various questioning strategies to strengthen the flipped classroom online method that I use. Although it is relatively new and seems complicated, I still get applied to using this online flipped classroom to make it easier for students to study more intensively at home and self-study before entering online class sessions. We prove this method to facilitate students in understanding narrative texts well (T2).

This statement is consistent with student responses, which revealed that: The flipped classroom method encourages me to study independently. The teacher guides me to find a correct answer from the narrative texts through redirection, prompting, and probing questions. This way makes it very easy for me to answer the series of questions asked by her correctly. It makes a positive impact on my knowledge, such as when the teacher asks: "What is the main idea of this story?" At first, I could not answer. She asked me to reread the first paragraph (Q133-T3). After reading, I immediately answered the Woman and the Cow. The teacher continued by directing me to answer the following question, "Anyone knows who the pathogenic character is!" I responded: "It is Wolf," she asked a follow-up question again, "Did the wolf kill Grandma?" I said no. Finally, she asked me to conclude the narrative text, The Old Woman and the Cow. I can easily explain it again (S2).

The subsequent student also revealed: Flipped classroom implemented by the teacher has facilitated me to study independently and more intensively so that I got a positive effect on increasing my knowledge. Like when the teacher asked, "What Bandung Bandawasa must meet conditions to marry Loro Jongrang?" I could answer this question well during the question-and-answer session in the online class (Q41-T2). I can answer it well. "Bandung Bandawasa has to build 1000 temples in one night." The next question "Why did Loro Jongrang ask for impossible conditions to do so?" (Q43T2) This question led me to a causal answer, and I answered it, "because he hates it" (S3).

Positive Feedback and Improve Reading Skills.

The third teacher stated: The third teacher revealed the need for careful preparation, starting from the digital teaching accessibility, internet signals to mastering literacy by the teacher. This preparation refers to questions level and questioning strategies that can lead students to understand narrative texts better. It required me to prepare thoroughly, including compiling digital teaching materials, ensuring the availability of 
a strong internet signal, and preparing narrative text assignments well. This way is so that the online teaching process can provide positive feedback for students (T3).

The second teacher also stated: I was happily using the online flipped classroom in teaching reading. Indeed, in applying this method, I have to prepare myself and have more time to prepare digital learning materials, upload them and then share them with all students. I also ensure that the internet signal is good so that the question-andanswer session process runs smoothly and provides positive feedback to improve students' reading comprehension skills (T2).

The following interview with other students said that: flipped learning methods and good teacher competencies make us easier to answer all teachers' questions correctly in the class. Of course, by supportable learning preparation, the availability of completed teaching materials, a strong internet signal, and good mastery of the subject, all these processes can provide positive feedback to improve my understanding of the narrative text reading material (S4).

\section{DISCUSSION}

The findings above showed that teachers make class discussions active and stimulate students enthusiastically in responding to every question asked. The ability of students to explain their answers with sound reasons is the success of students in completing the narrative text task given the previous week. Students have basic knowledge before they discuss and ask questions in an online class. The online-based flipped classroom learning method makes this easy. Douglas \& Frazier (2001) stated that questions are one of the best ways to develop the teacher's role as initiator and supporter in class discussions. This research showed the teachers' competence in applying five-question levels and three questioning strategies during teaching reading comprehension is good enough.

The three observed teachers have different competence in creating the five levels of questions in teaching reading. This research is consistent with Guszak (1967) stated that the questions that required students to recognize and remember the details of a text reached 78.3 percent. He reported that the teacher asked several questions, starting at a low level up to a high level. Risnanda (2018) supported and extended Guszak's findings that the ability of the teacher to create various questions is to improve students' reading comprehension. He pointed out that after observing the class for about 300 hours; he reported that most teacher questions guided student responses and did not challenge them to perform higher-order thinking operations.

When the teacher asked literal and reorganized level questions using a redirection strategy, students responded to this process highly enthusiastic, and in this context, students can give a motivated reaction. That's because some parts of the question relate directly to the text. By providing some clues, students can respond explicitly to the question asked. Therefore, when given literal and redirection questions, it made the interaction of students with their teacher run well. Students will be more active in answering the teacher's questions regarding topics, themes, characters, and settings at these levels. 
A question of "Do you understand?" is a question that showed the teacher's strategy to measure the level of understanding of his students. The teacher can find or identify the correct answer from the student's response. The results are in line with the research by Aydemir et al. (2013) revealed that evaluation questions require students to make an assessment. This question is to test students' ability to assess reading texts. They can understand the meaning of the text clearly or implicitly. To understand this meaning, students must have adequate background knowledge. To successfully analyze the correct answer, students must practice first. The exercise is answering the reading comprehension test. The researcher found that almost all teachers have good competence in creating and developing some evaluation questions intended to check students' reading comprehension of a text. We measured student's analytical ability to understand all information they got used questions levels and questioning strategies.

This study is consistent with Erten \& Karakaş (2007) revealed that using reorganization questions can lead students to understand the text based on literal understanding. For this reason, teachers must be able to develop question-and-answer learning strategies. They can assign students in advance to summarize and retell the narrative text they have read. Using inferential questions combined with probing, teachers can investigate students by asking questions stated in a text. When there is no response from the class, the teacher immediately helps students give additional clues to encourage students to arrive at the correct answer.

The teacher stimulates students with three levels of questions to guide them in higherorder thinking, namely inferential, evaluation, and appreciation. At this stage, the teacher demands students' analytical skills to understand narrative texts. According to Barrett's Taxonomy, it is a question that asks students' higher thinking skills to infer the message they get. In this way, students can infer information from the text using their own language. The teacher who made more questions at this level in class was T3. He could make 33 questions (14.2\%). Unlike T1, he only made 23 items (12.6\%). T2 is only six $(3.8 \%)$ of 233 questions that appeared during the lesson. It showed that the number of questions T3 is more create inferential question than T1 and T2.

This finding showed many differences in teacher competence in making various levels of questions and questioning strategies. Interestingly, mastery of literature and learning technology and the habit of asking questions in each learning session in class more influenced teachers' competence dominantly than their training background, years of service, and age. Teacher-1 could make literal and reorganized questions is better than $\mathrm{T} 2$ and T3, teacher- 2 and teacher- 3 more able to make evaluation questions are better than T1. For the appreciation questions, only teacher-3 could create this question. She also could combine five types of questions and questioning strategies better than others, even though she did not have more experience in teaching training like teachers- 1 and teachers-2 had.

This research is consistent with Chen \& Liang (2017) emphasized that the teacher's competence in making questions in narrative texts must consider the level of questions and questioning strategies. They revealed that experienced teachers and having excellent linguistic skills will be more adept at making five levels of questioning. Maksimović \& 
Dimić (2016) reported that nothing statistically significant difference referring to the variables: gender, tenure, and education regarding teachers' attitudes towards the importance of using ICT competencies in the classroom. Thus, the respondents realized the need and importance of using ICT in online teaching is as part of their professional development. D. Douglas (2000) and Ukoha (2015) revealed that anyone who develops the habit of reading will always look for something to read. They emphasized that one must become fully competent in reading comprehension to succeed in his academics.

But this result contradicts with Dos et al. (2016) reported that teachers' experience in obtaining pre-service education and training supports their competence in asking good questions. This difference occurs because their research applies a face-to-face learning mode directly in the classroom without being facilitated by using online learning technology. Their result showed that the teacher's ability to ask questions is in line with the increasing number of teachers' experiences received in pre-service education and training, however through virtual media, most teachers feel burdened with using it, which affects their literacy decline and decreasing the ability to ask verbally than faceto-face teaching in class. Pineteh (2012) stated that growing interest in computercentered teaching and learning is high at the Cape Peninsula University of Technology (CPUT)-South Africa with traditional teaching methods are still valuable, given the differences in learning styles and diverse technology experiences.

This finding is also consistent with studies by Javed et al. (2016) reported that the teacher-directed students with inferential questions to practice students' understanding of higher levels of thinking in understanding a text. At this stage, successful students are those who can conclude a text. They can also predict the storyline as they read the narrative text. Students can also re-explain the conclusions they made from the narrative texts they read.

To measure the understanding level demands higher-order thinking skills, it is possible to ask evaluation questions. On average, all teachers could apply this question level well. They assumed that to make students understand the text well, teachers must-reading material assignments first before discussion in the online class. The teacher's competence in creating various questions level and questioning strategies affects students' reading comprehension. This method has proven a more-lively question-answer atmosphere between teachers and students appeared.

This study is consistent with Alsowat (2016) revealed were differences between pre and post-experiment of the engagement scale. In addition, student satisfaction with the Flipped Classroom Teaching Model (EFL-FCTM) was high. He also reported that the relationship between higher-order thinking (HOT) and student engagement in reading comprehension was highly significant and between HOT and satisfaction, and between student engagement and satisfaction. Jdaitawi (2019) reported that this strategy promotes independent learning and increases students' social connectedness. Girmen \& Kaya (2019) revealed their activity measured the student involvement in question-andanswer with teachers and peers during discussions is part of the student's success in obtaining good grades on reading comprehension material. Muhid et al. (2020) said 
teachers have to own this competency to provide positive feedback to students. The ability to provide this feedback includes continuous questioning strategies so that students can answer a question correctly.

The result of content analysis regarding using Flipped Learning online in Reading Comprehension showed that this method provides positive feedback to teachers and students. There are at least three positive feedback: 1) making the learning atmosphere fun, influencing student involvement, and improving teachers' competence, 2). facilitate students' self-study, and 3) provide positive feedback to improve students' reading comprehension skills. This study is consistent with Murillo-Zamorano et al. (2019), who revealed four basic dimensions must possess in the flipped classroom to be successful in the 21 st century with Generation Z. They confirmed that Flipped Learning has a positive effect on students' knowledge, skills, satisfaction, and engagement.

\section{CONCLUSION}

The study results concluded that three observed teachers had good competence in applying the question level and questioning strategy to measure the level of students' understanding of the narrative text taught. This method has revived the discussion process in learning the reading comprehension subject with the online-based flipped classroom learning method. The question-and-answer feedback during the lesson has provided influence to strengthen students' understanding of narrative texts. The three observed teachers also showed the ability to use different questions, especially at the level of appreciation only T-3 who could make these questions better than others. For the inferential, evaluation, appreciation question level, and for provoking and probing questioning, teacher-3 can make these questions better than T-1 and T-2.

The recommendation for English teachers is to suggest that they need to improve their linguistic mastery in creating various questions level and questioning strategies better. They also have to practice their competence in applying distance learning by using synchronous flipped classroom teaching based on internet technology such as WhatsApp, Microsoft Teams, and Google Classroom. We limited this research data to taking oral question-and-answer sessions between teachers and students during online learning only. Meanwhile, all the data of written questions and answers via WhatsApp and Microsoft Team outside the class were unanalyzed because they mostly used code-mixing language.

\section{ACKNOWLEDGMENTS}

A big thank you to the Ministry of Religious Affairs of the Republic of Indonesia (MoRA) and the Doctoral Program of Educational Technology of the State University of Malang.

\section{REFERENCES}

Alsowat, H. (2016). An EFL Flipped Classroom Teaching Model : Effects on English Language Higher-order Thinking Skills , Student Engagement and Satisfaction. Journal of Education and Practice, 7(9), 108-121. 
Aydemir, Z., Öztürk, E., \& Horzum, M. B. (2013). The effect of reading from screen on the 5th grade elementary students' level of reading comprehension on informative and narrative type of texts. Educational Sciences: Theory and Practice, 13(4), 2272-2276.

Bloom, B. S., Engelhart, M. D., Furst, E. J., Hill, W. H., \& Krathwohl, D. R. (1956). Taxonomy of educational objetives: the classification of educational goals: handbook I: cognitive domain. New York, US: D. Mckay.

Brown, C. A., Danvers, K., \& Doran, D. T. (2016). Student perceptions on using guided reading questions to motivate student reading in the flipped classroom. Accounting Education, 25(3), 256-271.

Chavangklang, T., \& Suppasetseree, S. (2018). Enhancing Thai EFL university students' reading comprehension through a flipped cooperative classroom. PEOPLE: International Journal of Social Sciences, 4(3), 238-261.

Chen Hsieh, J. S., Wu, W.-C. V., \& Marek, M. W. (2017). Using the flipped classroom to enhance EFL learning. Computer Assisted Language Learning, 30(1-2), 1-21.

Chen, J. J., \& Liang, X. (2017). Teachers' literal and inferential questions and children's responses: A study of teacher-Child linguistic interactions during whole-group instruction in Hong Kong kindergarten classrooms. Early Childhood Education Journal, 45(5), 671-683.

Cooper, J. M. (2010). Classroom teaching skills. Cengage Learning.

Curtis, A. (2012). Colombian teachers' questions about CLIL: What can teachers' questions tell us?(Part II). Latin American Journal of Content \& Language Integrated Learning, 5(2), 1-12.

David, J., Paul, E., \& Donald, K. (1989). Method for Teaching, a skill Approach. Ohio: Merril Publishing Company.

Dean, R., Vacca, J., \& Vacca, R. (1986). The Influences of Anticipation on Readers' Response to a Basal Short Story. Reading Horizons: A Journal of Literacy and Language Arts, 26(3), 9.

Dhillon, B. P. S., Herman, H., \& Syafryadin, S. (2020). The Effect of Skimming Method to Improve Students' Ability in Reading Comprehension on Narrative Text. Linguists: Journal Of Linguistics and Language Teaching, 6(1), 77-88.

Dos, B., Bay, E., Aslansoy, C., Tiryaki, B., Cetin, N., \& Duman, C. (2016). An analysis of teachers questioning strategies. Educational Research and Reviews, 11(22), 20652078.

Douglas, D. (2000). Assessing languages for specific purposes. Ernst Klett Sprachen.

Douglas, D. A. N., \& Frazier, S. (2001). Teaching by Principles: An Interactive Approach to Language Pedagogy .: H. Douglas Brown. Tesol Quarterly, 35(2), 341-342.

Erten, I. H., \& Karakaş, M. (2007). Understanding the divergent influences of reading 
activities on the comprehension of short stories. Reading, 7(3).

Girmen, P., \& Kaya, M. F. (2019). Using the Flipped Classroom Model in the Development of Basic Language Skills and Enriching Activities: Digital Stories and Games. International Journal of Instruction, 12(1), 555-572.

Gough, P. B., \& Tunmer, W. E. (1986). Decoding, reading, and reading disability. Remedial and Special Education, 7(1), 6-10.

Guszak, F. J. (1967). Teacher questioning and reading. The Reading Teacher, 21(3), 227-234.

Harrison, S. L. (n.d.). Improving Online Tertiary Education in the Developing World Based On Changes in Perceptions Post COVID-19.

Henderson, D., Woodcock, H., Mehta, J., Khan, N., Shivji, V., Richardson, C., Aya, H., Ziser, S., Pollara, G., \& Burns, A. (2020). Keep calm and carry on learning: using Microsoft teams to deliver a medical education programme during the COVID-19 pandemic. Future Healthcare Journal, 7(3), e67.

Javed, M., Eng, L. S., Mohamed, A. R., \& Ismail, S. A. M. M. (2016). Identifying reading strategies to teach literal, reorganisation and inferential comprehension questions to esl students. Journal of Asia TEFL, 13(3), 204.

Jdaitawi, M. (2019). The Effect of Flipped Classroom Strategy on Students Learning Outcomes. International Journal of Instruction, 12(3), 665-680.

Joseph, L. M., Alber-Morgan, S., Cullen, J., \& Rouse, C. (2016). The effects of selfquestioning on reading comprehension: A literature review. Reading \& Writing Quarterly, 32(2), 152-173.

Kim, Y.-S. G., \& Petscher, Y. (2020). Influences of individual, text, and assessment factors on text/discourse comprehension in oral language (listening comprehension). Annals of Dyslexia, 1-20.

Lai, C., Yeung, Y., \& Hu, J. (2016). University student and teacher perceptions of teacher roles in promoting autonomous language learning with technology outside the classroom. Computer Assisted Language Learning, 29(4), 703-723.

Lervåg, A., Bråten, I., \& Hulme, C. (2009). The cognitive and linguistic foundations of early reading development: a Norwegian latent variable longitudinal study. Developmental Psychology, 45(3), 764.

Liu, H. (2020). Does questioning strategy facilitate second language (L2) reading comprehension? The effects of comprehension measures and insights from reader perception. Journal of Research in Reading.

Maksimović, J., \& Dimić, N. (2016). Digital technology and teachers' competence for its application in the classroom. Istraživanja u Pedagogiji, 6(2), 59-71.

Martin, L., \& Tapp, D. (2019). Teaching with Teams: An introduction to teaching an 
undergraduate law module using Microsoft Teams. Innovative Practice in Higher Education, 3(3).

Muhid, A., Amalia, E. R., Hilaliyah, H., Budiana, N., \& Wajdi, M. B. N. (2020). The Effect of Metacognitive Strategies Implementation on Students' Reading Comprehension Achievement. International Journal of Instruction, 13(2), 847-862.

Murillo-Zamorano, L. R., Sánchez, J. Á. L., \& Godoy-Caballero, A. L. (2019). How the flipped classroom affects knowledge, skills, and engagement in higher education: Effects on students' satisfaction. Computers \& Education, 141, 103608.

Perfetti, C. A. (1976). Reading Comprehension Depends on Language Comprehension.

Pineteh, E. A. (2012). Using virtual interactions to enhance the teaching of communication skills to information technology students. British Journal of Educational Technology, 43(1), 85-96.

Risnanda, R. (2018). Cognitive Level of Reading Questions in English Textbook for Senior High School. UMSU.

Sencibaugh, J. M., \& Sencibaugh, A. M. (2015). The effects of questioning the author on the reading comprehension of middle school students. Reading Improvement, 52(3), $85-92$.

Smith, R. J., \& Barrett, T. C. (1979). Teaching reading in the middle grades. Addison Wesley Publishing Company.

Ukoha, E. K. (2015). Impact of writing on improving the reading competence of Nigerian adolescents. International Journal of Technology and Inclusive Education, $4(2), 647-653$ 